\title{
Vakıflar Dergisi
}

Yıl: Aralık 2019 • Sayı: 52 


\title{
IÇINDEKILER / CONTENT
}

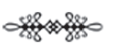

Bursa Emir Sultan Külliyesi Vakıfları (Kuruluşundan XVII. Yüzyıl Sonuna Kadar)

The Waqfs of Bursa Emir Sultan Kulliye (from Establishment until the end of XVIIth Century)

Nilüfer Ateş

Osmanlı Dönemi'nde Tokat Ali Paşa Camii Vakıfları.

Waqfs of Ali Pasha's Mosque in Tokat During the Ottoman Period

Ali Açıkel

Midilli'de Kreokopou Manastırı Arazi Gelirini Paylaşma Mücadelesi ve Aziz Mahmud Hüdâyî Vakfi .

The Struggle for Income Sharing of Kreokopou Monastery in Lesvos and Aziz Mahmud Hüdâyî Waqf

İbrahim OĞUz

Hasankeyf İmam Abdullah Camii ve Zaviyesi Vakfi (16-18. Yüzyıllar)

Imam Abdullah Mosque and Zawiyah Waqf in Hasankeyf

Mehtap Nasıroğlu

18. Yüzyılda Hayırsever Bir Padişah Kadını: Vuslat Kadın'ın Medine ve İstanbul Vakıfları ....

A Philanthropist Consort of Ottoman Sultan in the 18th Century: The Case of Vuslat Kadin's Medina and Istanbul Waqfs Abdullah Çakmak

Osmanlı Döneminde Safranbolu Para Vakıfları....

Safranbolu Cash Waqfs in the Ottoman Period

Abdulkadir Atar

Çemişgezek Hamidiye Medresesi

Hamidiye Madrasah in Cemisgezek

Celalettin Uzun

Basra'daki Sahabe Türbe ve Mescitleri ile Vakıflarının Osmanlı Dönemindeki Durumu.

The Status of the Tombs and Masjids in Basra that belong to the Prophet's Companions and Their Waqfs in the

Ottoman Period

Reyhan Şahin Allahverdi

Osmanlı Macaristanı'nda Tekkeler, Türbeler, Şehitlikler ve Mezar Taşları.

Dervish Lodges, Tombs, Martyrs Burial Sites and Tomb Stones in Ottoman Hungary

Mehmet Emin Yılmaz

Topografik Etmenlerin İzinde: Edirne Selimiye Külliyesi

Following the Topographical Factors: The Selimiye Complex in Edirne

Murat Sav

Kitabiyât.

Book Review

Mihrişah Valide Sultan Vakfi

Yılmaz Kurt

Vakıflar Dergisinden Seçmeler - IV

Yusuf Turan Günaydın 



\title{
Basra'daki Sahabe Türbe ve Mescitleri ile Vakıflarının Osmanlı Dönemindeki Durumu*
}

\author{
Reyhan Şahin Allahverdi**
}

Öz

Bu çalışmada Basra'da bulunan Hülefâyı Raşidîn'in sonuncusu olan Hz. Ali'nin adını taşıyan cami ile Aşere-i Mübeşşere'den Hz. Zübeyr bin Avvâm, Hz.Talha bin Ubeydullah ve son sahabî Hz. Enes bin Mâlik ile "tabiinden" Hz. Hasan-ı Basrî’nin isimlerini taşıyan türbe ve mescitlerin vakıfları ele alınacaktır. Basra, Osmanlı hâkimiyetine geçtikten sonra sözkonusu vakıflara ait mescit ve türbelerin kayıtları da Osmanlı idaresi tarafindan tutulmaya başlanmıştır. Ancak vakıflara dair, en azından şimdilik ulaşabildiğimiz ilk kayıtlar, 17. yüzyılın sonralarında (1690-1695) tutulan vakıf muhasebe defterleridir. Bu defterlere göre Hz. Ali Mescidi (Makam-ו Ali Cami') ile Hz. Zübeyr'in türbesi ve mescidi; Hz.Talha, Hz. Enes ve Hz. Hasan-ı Basrî”ye ait türbeler birbirine yakın yerlerdedir. Hz. Ali Cami' vakfi müstakil olarak gösterilirken, diğer dört vakfin tamamı ortak mütevelli tarafindan idare olunmaktadır. Dört vakfin bazı işleri ortaklaşa yapıldığı gibi vakıfların bazı vazifelileri ayrı ayrıdır. Vakıfların en büyüğü Hz. Zübeyr'in vakfidır; dolayısıyla vakfin bütün vazifelileri sadece onun türbe ve mescidinde görevlidir.

17. yüzyıl seyyahlarından Evliya Çelebi'nin de gördüğü ziyaretgâhların ve vakıfların durumu bu yüzyılın sonuna kadar takip edilebilmekteyken, 18. yüzyılda bölgedeki Osmanlı idaresinin zayıflamasından dolayı, vakıflara ait kayıtlar da kesintiye uğramaktadır. Dolayısıyla bu yüzyılda ziyaretgâhlar ve vakıflarına dair elimizde bir bilgi bulunmamaktadır. 19. yüzyıla gelindiğinde ise bölgede yeniden Osmanlı otoritesi kurulduktan sonra ziyaretgâhların fiziki durumlarına dair yeni bilgiler Osmanlı arşiv kayıtlarına yansımaktadır. Buna göre Osmanlı idaresi, ziyaretgâhların yıkılan ve eskiyen yerlerini tespit ettirmiş ve tamir girişimlerinde bulunmuştur. Basra dolayısıyla Irak, hem siyasi ve stratejik hem de dini açıdan Osmanlı́nın önem verdiği bir bölgedir. Ayrıca bu vakıflar, sıradan vakıflar olmayıp, bir İslam İmparatorluğu olan Osmanlı Devleti'nin sultanı ve aynı zamanda İslam halifesinin himaye ettiği dinin ilk inananları olan "kutsal" kişilere aittir.

Anahtar Kelimeler: Sahâbe, Basra, vakıf, Osmanlı, türbe

\section{The Status of the Tombs and Masjids in Basra that belong to the Prophet's Companions and Their Waqfs in the Ottoman Period}

\section{Abstract}

In this study, the mosque bearing the name of Ali, the last one of Hulefâyı Raşidin (The Rashidun Caliph) and the waqfs of tombs and masjids bearing the names of Zübeyr bin Avvam from Aşere-i Mübeşşere, Talha bin Ubeydullah, Enes bin Malik, the last companion of the prophet, and Hasan-ı Basri from "tabiin" (the dependents) will be discussed. Records of the mosques and tombs belonging to the waqfs were kept by the Ottoman administration. However, the first records of waqfs that we have at least for now are the accounts of the waqfs kept in the late 17th century (1690-1695). According to these records, Ali Masjid (Makam-ı Ali Cami') with the tomb and masjid of Zübeyr and tombs belonging to Talha, Enes and Basrî are close to each other. While the waqf

* DOI: $10.16971 /$ vakiflar.547239

Makale Türü / Article Type: Araştrma Makalesi / Research Article

Makalenin Geliş Tarihi / Received Date: 31.03.2019

Makalenin Kabul Tarihi / Accepted Date: 17.09.2019

Makale Rapor Durumu: Makale, iki akademik hakemin inceleme raporları neticesinde yayınlanmıştr.

Article Report Status: The article was published as a result of the review reports of two academic referees.

** Doç.Dr., Burdur Mehmet Akif Ersoy Üniversitesi, Fen-Edebiyat Fakültesi, Tarih Bölümü. rey.sahin34@gmail.com; ORCID: https://orcid.org/0000-0002-5147-4412 
of the mosque of Ali were remarked as müstakil (independent), the other four waqfs were managed by a joint mütevelli (trustee). Some of the works of the four waqfs were done jointly while some of the functions of the waqfs were separate. The biggest waqf among them was Zübeyr's waqf; therefore, all servants of the waqf were assigned only to his tomb and masjid.

While the situation of ziyaretgâhs (the place of pilgrimage) and waqfs visited by Evliya Çelebi, one of the 17th-century travellers could be traced until the end this century, due to the weakening of Ottoman administration in this region, the records of the waqfs have been cut in the 18th century. Thus, we do not have any information about the physical structures of ziyaretgâhs and waqfs can be found in Ottoman archives. In the 19th century, after re-establishment of the Ottoman authority in the region, the physical entities of the ziyaretgâhs were reflected in the Ottoman archives. Owing to this, the Ottoman administration has determined perished and frazzling places of ziyaretgâhs and made attempts to repair them. Basra, hence Iraq was an important region that the Ottoman Empire has attached importance to both politically, strategically and religiously. Besides, these waqfs were not ordinary ones but belonged to the people whom they regard as sacred in the context of being in an Islamic Empire and in terms of the sultan's position representing the Caliphate.

Key Words: the Companion of the prophet, Basra, waqf, Ottoman, tomb 


\section{Giriş}

Basra siyasi ve dini kimliği her zaman ön planda olan Irak coğrafyasındaki en önemli şehirlerden biridir. Basra'nın gerek İslam Devleti, gerek Osmanlı dönemi siyasi tarihiyle, Osmanlı-Safevî mücadelesine dair yapılmış pek çok çalışma bulunmaktadır. Şehir, Basra Körfezi'ne kıyısı olması sebebiyle, özellikle 16. yüzyılda Portekizlilerin ve daha sonra diğer sömürgeci devletlerin ilgisini çekiyordu. Deniz yoluyla Hint Okyanusu'na ve Akdeniz'e bağlanan ticaretin, önemli kavşak noktalarından biridir. Gerek askeri, gerek ticari yönünü inceleyen çalışmalar yapılmış olmakla beraber, Basra'da medfun Sahabe'ye ait türbe ve mescitlerle vakıfları, tarihçiler tarafindan üzerinde yeterince durulmayan konulardandır.

Basra'da bulunan Sahabe türbelerine dair yapılan bu çalışmanın en önemli kaynağı, Devlet Arşivleri Başkanlığı Osmanlı Arşivi(BOA)'nde bulunan vakıf defterleridir. Bu defterlerden dördü 17. yüzyılın sonuna ait vakıf vazife/yevmiye defteridir. Bu defterler sayesinde vakıfların, Osmanlı idaresinde işlerinin aksamadan yürütüldüğü, cihetlerin kimin uhdesinde olduğu ve ne kadar yevmiye aldıkları tespit edilebilmektedir. Bunlar Maliyeden Müdevver (MAD), Kamil Kepeci (KK) ve Haremeyn Muhasebeciliği (HMH.d) fonuna ait defterlerdir. 18. yüzyılda ise vakıfların arşiv kayıtları kesintiye uğramaktadır. Bunun nedeni bu yüzyıl boyunca, Basra'da Osmanlı'nın tam olarak hakimiyet sağlayamamasıdır. 19. yüzyılda, bölgede Osmanlı hükümeti tarafindan yeniden, istikrar ve kontrol sağlandıktan sonra ise arşiv kayıtlarının tekrar düzenli bir hal aldığı görülmektedir.

Salnameler, Seyahatnameler ve coğrafya eserleri türbe ve mescitlerin araştrılmasında yine birinci elden kaynak grubunu oluşturmaktadır. Hz. Peygamber dönemini de eserinde ele alan Tarihçi Taberi'nin Tarihi, Basra'da meydana gelen siyasi olaylar ve Sahabe hakkında ayrıntılı bilgiler vermektedir. 14. yüzyılda bölgeyi gezen İbn Battûta'nın müşahadeleri ise türbelere dair ilk canlı anlatımlardır. Çalışmanın asıl odak noktasını oluşturan Osmanlı dönemi için ise arşiv belgeleri dışında, çeşitli seyahatname ve coğrafya eserlerinden yararlanılmıştır. 16. yüzyıla ait önemli bir seyahatnâme ve coğrafya eseri olan Menâzirü'l-Avâlim'in yazarı Âşık Mehmed Basra'nın coğrafî konumundan bahsettiği eserinde, İslam kaynaklarına dayanarak Hz. Muhammed ve Sahabe'nin siyasi ve dinî mücadelelerini kaleme almıştır. Bununla beraber, Âşık Mehmed'in eserinde türbelere ve vakıflara dair bahis bulunmamaktadır. 17. yüzyıla ait önemli ve birinci elden kaynak özelliği taşıyan Seyahatname'nin yazarı Evliya Çelebi, Basra'da bulunmuş ve gözlemlerini aktarmıştır. 19. yüzyılın sonunda yayınlanan Ali Cevad'ın coğrafya eseri Memâlik-i Osmâniye'nin Tarih ve Coğrafya Lügat ise Basra'nın coğrafi özellikleriyle idari taksimatına dair genel bilgiler vermesinin yanısıra, Sahabe türbelerinin varlığından bahsetmektedir.

Seyahâtnâme-i Hudûd, Osmanlı-İran sınır anlaşmazlığının giderilmesi için 1847'de Erzurum'da toplanan uluslararası bir komisyonda, Osmanlı Devleti'ni temsil eden Derviş Paşa başkanlığındaki Türk heyetinde bulunan Mehmed Hurşid Paşa tarafindan kaleme alınmıştır. Eser, o tarihlerde Osmanlı sınırları içinde bulunan Irak bölgesiyle İran Devleti'ni ayıran sınırdaki anlaşmazlığın halli için toplanan komisyonunun, Erzurum'dan Basra'ya kadar olan ve dört yıl süren seyahatlerini (1848-1852) içermektedir.

VII. yüzyılda Hz. Ömer zamanında Araplar tarafindan kurulan (Bakır, 1992: 108) Basra şehri bulunduğu konum nedeniyle Müslümanların kendi aralarındaki mücadelelere sahne olduğu gibi, dışarıdan gelen saldırılara da maruz kalmıştır. Buna rağmen hiçbir zaman İslam dünyası dışından bir devletin idaresine girmeyen Basra, Osmanlı hâkimiyeti dönemi de dâhil İslam medeniyetinin geliştirdiği önemli şehirlerdendir. Bu bakımdan bu medeniyetin kurucularının, bu bölgede yaptığı diğer hizmetler bir tarafa konursa, şehre önemli eserlerle, o eserleri ayakta tutacak vakıflar bırakmışlardır. 
Çalışmaya konu olan hazerât ve zevâtın (sahabe ve aşere-i mübeşşere) ${ }^{1}$ çoğu şehrin yerlisi olmadığı gibi Basra'ya gelişleri ve bu şehirle bağlantıları İslam dininin iç çatş̧malarının bir sonucudur. Basra, İslam Devleti zamanında önemli siyasi olayların merkezinde olan bir şehirdi. Bilhassa hilafet meselesinde $\mathrm{Hz}$. Osman'ın öldürülmesiyle sonuçlanan ayaklanmalara ve nihayetinde onun intikamını almak isteyen $\mathrm{Hz}$. Aişe'nin liderliğinde ve $\mathrm{Hz}$. Ali taraftarlarına karşı cereyan eden Cemel Vakası'na sahne olmuştu (Hicri 36/Aralık 656). İncelememize konu olan türbe ve mescitlerin sahipleri olan $\mathrm{Hz}$. Talha bin Ubeydullah ve Hz. Zübeyr bin Avvâm'ın da öncülük ettiği grup Hz. Aişe'nin yanında yer almışlardı. İslam tarihi açısından oldukça trajik olan olayda Zübeyr bin Avvâm, Talha bin Ubeydullah ve Enes bin Malik² gibi sahabe şehit olurken, 5000 Basralı hayatını kaybetti. Basra, bu olaylardan sonra Şiilere karşı Irak'ta Sünnîliğin merkezi mesabesine yükselmişti (Bakır, 1992: 109)³.

Hz. Osman'ın halifeliği zamanında Arapların Basra'dan geniş araziler almasına izin veriliyordu. Ganimet sayılan bu araziler sayesinde zenginleşenler arasında sahabeden $\mathrm{Hz}$. Zübeyr'in 1000 kadar kölesinin olduğu ve bunların ticaretle uğraştğı rivayet edilmektedir. Keza Talha bin Ubeydullah da, Basra'nın zengin tacirleri arasında sayılmaktadır. Hz. Talha'nın Basra'da Kanât adıyla ün salmış arazisinde, oldukça verimli tarla ve çiftlikleri vardı. Öldügünde servetinin mal ve gayrimenkul olarak 30 milyon dirhem olduğu kaydedilmektedir (Bakır, 1992: 110). Cemel Vakası sırasında el konulan bazı gayrimenkulleri Hz. Ali tarafindan çocuklarına geri verilmişti (Erul, 2010: 505).

Basra, Emevilerden sonra Abbbasilerin hâkimiyetinde iken Selçuklu Sultanı Tuğrul Bey'in 1055 Bağdat seferiyle Selçukluların himayesine girdi (Çekim, 1996: 12). 1258'de Moğolların Irak'ı işgalinden sonra, Basra sırasıyla 1335'te İlhanlılar, 1383'te Timurlular, 1410 Karakoyunlular, 1470 Akkoyunlular ve OsmanIı ilhak etmeden kısa bir süre önce 1508'de Safeviler tarafindan zapt edildi (Bakır, 1992: 111). XV. asrın sonuna kadar Musul ve havalisi ile Basra körfezi civarı Sünnîlerin kontrolü altındayken, Safevî Devleti'nin kurulmasıyla beraber, Şah I. İsmail zamanında (1501-1524) Şiîler, Irak'ta etkisini arttırmaya başladı. Öyle ki Sünnîlik şiddetle bastırıldığı gibi, sûfi türbeleri tahrip edilirken, Şiî imamların türbelerini ziyaret ön plana çıkarıldı. Irak'ta, Şiîlerce mukaddes sayılan bazı ziyaret yerleri (atebât şehirleri) birer hac merkezine dönüştürülmüş, Mekke ve Medine'den daha mukaddes kabul edilmişlerdi (Poş, 2011: 49, 53).

Kanunî Sultan Süleyman zamanında 1534'te Safevîlerin elinde bulunan Irak'a yapılan seferler sonucunda, Osmanlı idaresine giren Basra'nın, Osmanlı idari teşkilatına dâhil edilmesi 21 Şevval 952/26 Aralık 1545'te Bağdat Beylerbeyi Ayas Paşa ve Musul Sancak Beyi Mehmed Bey'in gayretleriyle gerçekleşmişti. Mehmed Bey bu sayede bir milyon akçe salyane ile Basra'ya atanan ilk beylerbeyi olmuştu (Allahverdi, 2016: 53-54). 1555'te Safevîlerle yapılan Amasya Antlaşması ile İran şahı da Basra'nın hukuken Osmanlı hâkimiyetinde olduğunu kabul ediyordu (Halaçoğlu, 1992: 112).

17. yüzyılda Osmanlı Devleti'nin Avrupa'da Viyana kuşatmasıyla başlayan yenilgiler ve uzun savaşlarla uğraşmasını değerlendiren Müntefik Şeyhi Mâni' Arap aşiretlerini kışkırtarak Basra'da ayaklanmışt. Basra'da istikrarın bozulmasıyla Safevî kuvvetleri Mâni'yi yenerek Basra'ya hakim oldular. Osmanlı hükümeti Karlofca Antlaşması'yla batıdaki savaşları bitirir bitirmez (1690-1691) Basra meselesini ele alarak, 1701'de Basra'da yeniden hakimiyeti sağladı. 1720 yılından itibaren bölge üzerinde Osmanlı Safevî

1 Kaynaklarda "el-aşeretü'l-mübeşşere”, "el-mübeşşerûn bi'l-cenne”, "el-aşeretü’l-meşhûdü lehüm bi'l-cenne” gibi ifadelerle anılan bu on sahâbî Ebû Bekir, Ömer, Osman, Ali, Talha b. Ubeydullah, Zübeyr b. Avvâm, Abdurrahman b. Avf, Sa'd b. Ebû Vakkās, Ebû Ubeyde b. Cerrâh ve Saîd b. Zeyd'dir. Ashaptan Saîd b. Zeyd'in bir rivayetinde bu on kişiden Ebû Ubeyde b. Cerrâh yerine Abdullah b. Mes'ûd zikredilmektedir (Aydınlı vd. 1991: 547).

2 Bk. Canan (1995: 234-235).

3 Sahabe'nin Basra'ya gelişiyle söz konusu siyasi mücadeleler hakkında geniş bilgi için bk. Taberî (1991). 
savaşları tekrar başladığı gibi, Basra 1737'den itibaren Bağdat valisi tarafindan idare edilmeye başlandı (Demirtaş, 2013: 92, 97, 101). 18. yüzyıl boyunca bir tarafta Avusturya diğer tarafta Rusya ile savaş halinde olan Osmanlı, Basra'daki asi aşiretler üzerinde kontrolü sağlayamıyordu. Bu nedenle bu yüzyıl boyunca, Safevîler ve Müntefik aşireti Basra'da idareyi ellerine geçirmek için Osmanlı'ya karşı mücadele ettiler. Nihayet I. Abdülhamid zamanında 1779-1780'da Basra'da yeniden Osmanlı hakimiyeti sağlanabildi. Bu tarihten sonra ise Basra'ya tayin edilen mütesellimlerin disiplinsizlikleri ve Müntefik aşireti reislerinin tam olarak itaat altına alınamaması, Bağdad valilerini devamlı olarak uğraştırıyordu. Bu nedenle 19. yüzyıla kadar Basra'da tam bir idari istikrar sağlanamadı (Eroğlu vd., 2005: 60-62).

\section{Basra Ziyaretgâhları}

Basra'daki en önemli ziyaretgâhlar Sahabe'yle tabiîne ait türbe ve mescitlerdir. Belgelerde kendilerinden "sahâbe-i kirâmdan, aşere-i mübeşşereden" ve mezarlarından "merâkıd-ı mübâreke" olarak bahsedilmektedir. Türbe ve mescitler Osmanlı zamanında Basra eyaletinin Zübeyr kasabasında bulunmaktadır. Hicri 17/Miladi 639 yılında Hz. Ömer tarafindan inşa edilen eski Basra, daha sonradan terkedilerek, önceki şehre $5 \mathrm{~km}$ daha batıda yeniden kurulmuştu. Dolayısıyla Miladi 12. yüzyıldan itibaren eski Basra'nın bulunduğu yer Zübeyr şehri/kasabası olarak adlandırılmıştır (Ibn Battûta, 2000: I, 268). Kasabanın ismi de burada medfun bulunan Hz. Zübeyr bin Avvam'dan gelmektedir. Söz konusu ziyaretgâhlar Basra'da birbirine yakın mesafelerde bulunuyorlardı.

Ali Cevâd'ın kaydına göre Zübeyr, Basra vilayetinde Amâre sancağına bağlı bir kazadır (1313: 421). Zira Basra vilayeti 1884'e kadar bazen vilayet, bazen de mutasarrıfık olarak yönetiliyorken, bu tarihte vilayet merkezi de olan Basra sancağı, Muntefik, Amara ve Necid sancaklarından müteşekkil bir vilayet haline getirildi. Bu dönemde Basra sancağı, merkez olan Basra kazasıyla birlikte, Kurna ve Kuveyt kazaları dahil üç kazadan meydana geliyordu. Basra kazasının merkezi Basra kazasına bağı 5 nahiye (Fav, Ebulhasip, Şattü'l-Arap, Zübeyir ve Harise) bulunuyordu (Eroğlu vd., 2005: 13).

19. yüzyılın sonlarında hala bir Osmanlı kenti olan Zübeyr'deki ziyaretgâhlara en yakın köyde yaşayan ahalinin ifadesine nazaran, burası Basra eyalet merkezine 6 saat mesafededir. Bu köyün arazisi sahrada, akarsuyun olmadığı, meyve veren ağaçların yetişmediği, sadece kuyulardan su taşınarak karpuz yetiştirilen bir yerdi. Ayrıca sık sık Arap eşkıyasının saldııı ve yağmalarına maruz kalıyordu (BOA, BEO, 302/22622). Başka bir kayda göre Zübeyr kasabası dolayısıyla Sahabe'nin mezarları Basra'ya iki saat mesafede bulunmaktadırlar ki bu tarif daha gerçekçidir (BOA, EV.MKT, 2511/28).

Zübeyr'de bulunan kutsal mekânlara dair en eski ve ayrıntılı bilgi 14. yüzyılın ilk çeyreğinde buraları gezen seyyâh İbn Battûta'ya aittir. İbn Battûta Seyahatnamesi'nde Basra'da bulunan ziyaretgâhları, özellikle “Aşere-i Mübeşşere'den başta Hz. Ali olmak üzere önemli zatların cami ve mescitleriyle bazılarının türbeleri hakkında önemli detaylar vermektedir. Buna göre o tarihte (Miladî 1326) Basra Hüzeyl mahallesi, Beni Haram mahallesi ve Acem mahallesi olmak üzere üç büyük semtten müteşekkildi (Iibn Battûta, 2000: I, 265).

İbn Battûta'nın Basra'da şehir merkezinden iki mil uzaklıkta, bulunduğunu ifade ettiği Hz. Ali Mescidi'ni "kale gibi bir bina" ve "oldukça dikkat çekici" şeklinde nitelemektedir. Öyle ki eskiden Basra çok daha geniş bir alanı kapladığından Mescit şehrin tam ortasında bulunuyordu. Oysa İbn Battûta'nın şehri gezdiği tarihte mescit ile şehrin arası iki mildir; hatta mescit ile Basra yyı kuşatan birinci surla arasında bile iki millik bir mesafe bulunuyordu. Diğer bir ifadeyle Mescit, şehir ile surun ortasındaydı (ibn Battûta, 2000: 
I, 654). Elimizdeki vakıf defterlerindeki yer tarifleri de ỉbn Battûta'yı doğrulamaktadır. Buna göre "Câmi'-i makâm-ı 'Ali der-hudûd-ı 'Aşşâr der-kurb-ı Basra”' şeklinde kayıtlıdır (BOA, KK.d., 3377, vr.41).

O zaman, Basralılar Cuma namazını söz konusu Hz. Ali Mescidi'nde ifa ederlerdi ve diğer zamanlarda mescidin kapısı kapatılırdı. Orası yalnız Cuma günleri ibadete mahsus bir yerdi. Hz. Ali Mescidi, bölgedeki en güzel mescitlerdendi; oldukça geniş avlusu, Vadi's-Siba'dan getirilmiş kızıl çakıl taşlarıyla döşenmişti. Hz. Osman'ın, şehit edildiği sırada okuduğu Mushaf bu mescitte bulunuyordu. ỉbn Battûta, tam da «Allah, onlara karşı sana yeter. O duyandır, bilendir!» ayet-i kerimesinin bulunduğu sayfada kan lekesi olduğunu bizzat müşahede etmektedir. Hatta kaldığı sürede bu camide bir defa Cuma namazını dahi kılmıştır. "Hatip ayağa kalkıp hutbe okumaya başladı ve birçok hata yapt. Bu işe hayret ederek durumu Kadı Hüccetüddin'e anlattım. Kadı efendi: "Bu şehirde dilbilgisine vâkıf, kelimenin nasıl okunduğundan haberdar kimse kalmadı!" cevabını verdi. Oysaki Basralılar eskiden beri "nahiv" [gramer] ilminde önder olmuştur."

“Hz. Ali Mescidi'nin yedi minaresi vardı ve ahalinin inancına göre minarelerden biri, Ali'nin ismi anılınca zangır zangır titrerdi" diyen Battûta, durumu kendisi de deneyip gözlemlediğini şöyle nakletmektedir:

"Yanımda Basralılar varken mescidin üst tarafindan o minareye çıktım. Köşelerinden birine duvarcıların kullandığı cinsten, malaya benzer bir tahta çakılıydı. Yanımda bulunan adam elini bu tahtanın üzerine koyup: 'Müminlerin emiri Ali'nin başı için titre!' diye seslenince tabi ki önce tahta sonra da minare hakikaten sallandı! Ben de tahtayı elimle kavrayarak: 'Allah'ın elçisinin halifesi Ebubekirsin başı için titre!' deyince minare yine titredi. Orada bulunanlar buna hayret ettiler." (ibn Battûta, 2000: I, 264).

Ancak Hz. Ali Cami/Mescidi'nden günümüzde eser kalmamıştır (Bakır, 1992: 111).

Cemel Vakası'nda Hz. Aişe'nin yanında bulunan sahabeden Hz. Talha, Mervân b. Hakem tarafindan öldürülmüştü (Cemâziyelâhir 36/Aralık 656). Kabri Basra'nın dışındadır (Erul, 2010: 505). İbn Battûta, Hz. Ali Camii'nden sonra Talha b. Ubeydullah'ın türbesini ziyaret ettiğine göre birbirlerine yakın yerlerde olmalılar: "Şehrin içinde bulunan kabrin üzerinde bir kubbe var. Yanı başında bir mescit ve misafirleri doyurmaya mahsus bir zaviye mevcuttur. Basralılar bu kabre çok saygı gösterirler" (Ibn Battûta, 2000: I, 265). 2007 yılında Irak'ta mezhep çatışmaları dolayısıyla meydana gelen olaylarda Talha bin Ubeydullah Türbesi yerle bir edilmişti. ${ }^{4}$

Zübeyr bin Avvâm'ın kabri kendi adını taşıyan Zübeyr şehrine yakın bir yerde, Mirbed'dedir (ibn Battûta, 2000: I, Çevirmenin notları: 268). Zübeyr, Cemel Vakası sırasında Vâdissibâ’ denilen yerde namaz kıldığı sırada şehid edilmişti (Aralık 656). Burada Zübeyr b. Avvâm adına bir cami ve türbe yapılmışt. Yakın geçmişte ortaya çıkan Şiî-Sünnî çekişmelerinde Zübeyr'in türbesi Şiîler tarafindan tahrip edilmişse de son yıllarda onarılmıştı (Efendioğlu, 2013: 523). İbn Battûta'nın bu seyahatinde ziyaret ettiği kabirlerden bir diğeri Hz. Peygamberin arkadaşı ve halasının oğlu Zübeyr b. Avvâm’ın mezarıdır. Şehir dışında bulunan türbenin üzerinde kubbesi yoktur; yanı başında bir mescidi ve yolcuların doyurulduğu bir zaviyesi mevcuttur (ibn Battûta, 2000: I, 265). Resmi belgelere göre II. Abdülhamid döneminde defalarca tamir girişiminde bulunulan türbe ve cami "dünyanın her yerinden gelen seyyah ve Müslümanların ziyaret ve

42007 yılında, Basra'nın 25 kilometre uzağındaki Zübeyr yakınlarındaki Talha ibn Ubeydullah türbesine gelen bir grubun fotoğraf çekmek istediğini söyleyerek türbeye girdikleri ve etrafina yerleştirdikleri bombaları patlattkları açıklandı. Birkaç dakika arayla meydana gelen iki patlamada türbenin iki kubbesi ile minaresinin tamamen yıkıldığını ifade eden General Musavi, türbenin bekçilerin tutuklandığını söyledi. (https://www.yenisafak.com/dunya/sahabe-turbesi-bile-bombalandi-50596 E.T. 27 Mart 2019). Bkz. Ekler 1. 
ibadet ettiği mekânlardır (BOA, BEO, 2620/196433). Ancak Zübeyr şehri 1991 Körfez Savaşı'ndaki bombardımanla yıkıldı (ibn Battûta, 2000: I, Çevirmenin notları: 268).

Bir diğer mezar ise Hz. Peygamber'in sütannesi Halime'ye ait olup, yanında, onun oğlu ve Hz. Peygamberin sütkardeşi olan çocuğun kabri bulunmaktaydı. İbn Battûta'ya göre Peygamber dostlarından Hz. Ebubekir'in mezarı da bu şehirdedir ve üzeri kubbeyle örtülüdür (ibn Battûta, 2000: I, 265). Diğer yandan elimizdeki arşiv kayıtlarında bu kabir/türbeye dair bir vakıf kaydı yoktur.

Sahabeden Enes bin Mâlik ise Ensar içinden Hazrec kabilesindendir ve küçük yaşta İslam’a girmiş, Hz. Peygamber uzun yıllar hizmet etmiştir. Hafizasının kuvvetli olmasından, bahsedilmektedir. Ayrıca hadis ve fikıh ilminin de öncülerden olan Enes b. Malik, bir asırdan daha fazla yaşamış, 93/712 yılında 100 yaşını geçmiş olarak Basra'da vefat etmişti. Evinin eski Basra'nın kuzeybatısında, şehre 14 km. uzaklıktaki Zaviye semtinde bulunduğu rivayet edilmekle birlikte bunun dışında Basra'da dört evinin daha bulunduğu kaydedilmektedir. Ayrıca bahçesindeki ağaçlar yıl da iki defa meyve vermekteymiş (Canan, 1995: 234-235). Enes b. Malik'in kabri Basra şehir merkezinden altı mil uzaklıkta yer alan Vâdi's-Sibâ' civarındadır. Ancak bu vadi vahşi hayvanların bulunduğu ıssız bir yer olduğundan kalabalık bir ziyaretçi kitlesi olmadıkça gitmenin mümkün olmadığı bir yerdir (ibn Battûta, 2000: I, 265). Muhtemelen, İbn Battûta da bu kabri görmemiştir ki bu konuda herhangi bir bilgi vermemektedir.

İbn Battûta'nın "Sahabeden sonraki ilk kuşağın efendisi” olarak nitelediği “tabiinden” Hasan b. Ebi'l-Hasan Basrî ile Muhammed b. Sîrîn, Muhammed b. Vâsi, Utbe Gulâm, Malik b. Dinâr, Habîb Acemî ve Sehl b. Abdullah Tüsterî́nin kabirleri de Basra civarındadır (İbn Battûta, 2000: I, Çevirmenin notları 268-269). O tarihte kabirlerin başucu taşları mevcuttu ve hepsinin üstünde kimin yattğ̆ ve vefat tarihleri bulunuyordu. Son saydığı kabirlerin tamamının o tarihte şehre üç mil uzaklıktaki eski surun sınırları içinde olduğunu belirtmektedir. Bunlardan başka Sahabe ve tabiinden, Cemel Vak'ası şehitlerinden pek çoğunun kabirleri de Basra'da bulunuyordu (ibn Battûta, 2000: I, 265).

Basra'da mezarı olan Hasan b. Ebi'l-Hasan Basrî, Emevî devrinde ilim çevresinden olup, öğrenciler yetiştiren, Basra'nın önemli âlimlerindendi. 110/728 yılında vefat eden Hasan Basrî, “ilmi, cesaretiyle ve dünya malına değer vermeyen biri olarak tanınmıştır. Emevi valisi Haccâc'ı kıyasıya eleştirmekten korkmamıştır. Tanıdıkları onun çok etkileyici bir konuşma üslubu olduğunu söylerler. Ömer b. Abdülaziz başa geçince Hasan-ı Basri'den öğüt istemiş; Hasan-ı Basri de ona uyarılarla dolu bir mektup göndermiştir" (ibn Battûta, 2000: I, Çevirmenin notları, 268; Bakır, 1992: 111). Hasan Basrî vefat ettiğinde 87 yaşındaydı. Türbesi, Zübeyir kasabasının dışında, kasabaya yarım saat kadar mesafede olup, ziyaretgâh olarak halk tarafindan ziyaret edilmektedir (Eroğlu vd., 2005: 38).

İbn Battûta'dan üç asır sonra, Evliya Çelebi, 17. yüzyılın ortalarında şehri gezmiş ve gözlemlerini ilgi çekici bir şekilde aktarmıştır. Bölgeye geldiğinde Basra IV. Murad zamanından, 1638-1639'dan itibaren ocaklık tabir olunur bir sancak olarak Basra hakimi Efrâsiyâb Paşa oğlu Hüseyin Paşa'nın idaresi altındaydı (Evliya Çelebi Seyahatnamesi, 2010: 4/2, 646). Evliya Çelebi Basra'yı gezip, bütün yönlerini yazdıktan sonra şehrin dini ve sosyal mekânlarına değinmektedir. Cami, imaret, hamam ve mektep gibi yerlere dair özet bilgiler vermekle beraber, şehrin idari taksimatına dair önemli ayrıntlardan bahsetmektedir (Evliya Çelebi Seyahatnamesi, 2010: 4/2, 648-650). Sıra şehrin ziyaretgâhlarının tasvirine geldiğinde ise, Evliya bu mekanların isimlerini ve bulundukları yerleri etraflıca tarif eder. Fakat Sahabe'nin türbe ve mescitleriyle ilgili gözlemlerini yine kısa tutarken, okuduğu tarih kitaplarından Sahabe'nin hayatlarına dair bazı bilgiler aktarmakla yetinmektedir. Evliya Çelebi, anlatımına Hasan-ı Basrî ile başlamaktadır. Bu 
konudaki en önemli ayrınt Basra şehrinin kapılarından güney tarafindaki kapının adının Hasan-ı Basrî olmasıdır. (Evliya Çelebi Seyahatnamesi, 2010: 4/2, 650) Seyyaha göre, Basra'nın kıble tarafina bakan Müşrak kapısından çıkıp, üç saat boyunca çöle doğru ilerledikten sonra Hasan-ı Basrî türbesine ulaşılıyordu. Evliya Çelebi her zamanki üslubuyla, bu zatın 170 yaşında vefat ettiğine değinirken, büyük bir türbede yattı̆ından başka bir bilgi vermemektedir (Evliya Çelebi Seyahatnamesi, 2010: 4/2, 657)

Seyyahın türbeleri sırasıyla dolaştığını varsayarsak, ikinci sırada Makam-ı Ali mescidi bulunmaktadır. Cami Makamı ismiyle andığı yerin o tarihte harap olmaya yüz tutuğunu, Hazret-i Talha yolu üzerinde ve onun türbesine bir saat mesafede olduğunu bildirmektedir. Üçüncü ziyaretgâhta medfun bulunan $\mathrm{Hz}$. Talha hakkında bazı kitabi bilgiler verdikten sonra türbenin hala bütün halkın ziyaret mekânı olduğundan bahsetmekle yetinmiştir. (Evliya Çelebi Seyahatnamesi, 2010: 4/2, 657-658) Osmanlı belgelerinde adı geçmeyen ve Evliya Çelebi'nin $\mathrm{Hz}$. Süleyman'ın vezirlerinden olduğunu ileri sürdüğü $\mathrm{Hz}$. Âsaf-ı Berhıyâ'ya ait bir ziyaretgâha değinerek "büyük bir ziyaretgâhtı" ifadesinden başka, yine onun hakkında da kitabi bilgiler vermiştir. Seyyah son olarak Hz. Enes b. Malik'in türbesini ziyaret etmiş fakat ziyaretgâha dair herhangi bir ayrınt vermemiştir. (Evliya Çelebi Seyahatnamesi, 2010: 4/2, 658) Evliya Çelebi'nin anlattklarından, bölgeyi ziyareti sırasında ziyaretgâhlara dair anormal bir durum tespit etmediği anlaşılmaktadır. Bir savaş izi, yıkıntı yahut ziyaretçilerin sayısı, türbelerin konumu gibi ayrıntıları sükut geçmiştir. Seyahatnamede, Makam Cami dışında, türbelerin yanı başında olan mescitlerden ve Zübeyr b. Avvâm türbesine dair herhangi bir bahis yoktur.

18. yüzyıl Basra'ya ait kaynaklar çoğunlukla, bölgedeki Osmanlı-İan savaşlarına; dolayısıyla Osmanlı idaresinin Basra'da yeniden hakimiyet sağlamak üzere yerli hakimlerle mücadelesine dairdir. Basra'da bulunan idari istikrarsızık nedeniyle bölgenin özel tarihine dair bilgileri aktaran kaynaklar kısıtlı yahut şimdilik mevcut değildir.

19. yüzyılın ortasında, Mehmed Hurşid Paşa'nın Basra'da sınır komisyonu görevindeyken gözlemlerini içeren Seyahâtnâme-i Hudûd'a göre ziyaretgâhlardan bazılarının bulunduğu Zübeyr kasabası Basra'nın doğusunda iki buçuk, üç saatlik mesafede olup, takriben 2000 haneden müteşekkil bir yerdir. Yazar kasabanın sosyal ve ticarî hayatına değindikten sonra, ziyaretgâhlardan bahsetmektedir. İlk olarak kasabaya adını veren Zübeyr b. Avvâm hazretlerinin türbesinin yine kendi adıyla anılan cami (mescit) içinde olduğunu ve bu tarihte türbedar ve kiliddarının bulunduğunu kaydeder. Diğer Aşere-i Mübeşşere ile Hasan-ı Basrî, İbn Şirîn ve Talha bin Ubeydullah hazretlerinin türbelerinin kasabaya onar dakikalık bir mesafede bulunduğuna işaret etmektedir. Enes bin Malik türbesi de yine Zübeyr kasabasından ve Basra merkezinden ikişer buçuk, üçer saat mesafede açık mahaldedir. Hurşid Paşa'ya göre bu türbeler kadim Basra şehrinin içindeyken, bu tarihte Hazreti Zübeyr ziyaretgâhı hariç hepsi açık ve boş çöldedir (Seyahatname-i Hudûd, 1997: 29-30). Hurşid Paşa'nın gözlemleri de yine türbelerin Basra'ya göre konumu ve mesafesi hakkında olup, binaların maddi durumu hakkında ayrıntı vermemektedir.

\section{Ziyaretgâhlara Ait Vakıflar}

Incelediğimiz evkaf defterlerindeki, Sahabe kabir/türbe ve onların yanında bulunan mescitlerin vakıf kayıtlarına göre Battûta'nın işaret ettiği mübarek zatlara ait olan binalardan Makam-ı Ali Mescit’i ile Hz. Talha, Hz. Zübeyr, Şeyh Hasan-i Basrî ve Hz. Enes bin Mâlik'in türbe ve mescitlerine ait vakıf görevlilerini intiva eden kayıtları mevcuttur. Basra'da bunların dışında yine Sahabeden diğer bazı kimselerin türbeleri de bulunuyordu (Ali Cevâd, 1313: 177; Eroğlu vd., 2005: 170-172). 
Burada ele alınan vakıflara dair dört adet vakıf defterinden, kesin olarak tarihini tespit ettiğimiz üç defter 1105-1106 (1694-1695) senelerine aittir. Kamil Kepeci tasnifinde olan 3377 numaralı defterin tam tarihinin tespit edilmesi oldukça güçtür. Defterin başından ilk 14 varakta Basra'daki vakıflardan birine ait bir vakfiyenin sureti kayıtlıdır. Bu suretin kayıt tarihi 21 Rebiülevvel 1155/26 Mayıs 1742'dir. Varak 16'dan itibaren Basra'da bulunan çeşitli mescit ve camilerin vakıflarında görev yapan vazifelilerin yevmiye kayıtları bulunmaktadır. Fakat bu kayıtların başlığında herhangi bir tarih yokken muhasebe kaydının sonuna 3 Cemaziyelevvel 1101/1689-1690 tarihi düşülmüştür. Vakfiye suretinden sonra defterde bulunan ilk tarih ise 1088/1677-1678'dir. Basra'daki vakıfların bazılarında meydana gelen değişiklerden dolayı eklemeler yapıldıkça, ilgili muamelenin altına tarihleri yazılmıştır (1094, 1098 ve 1102...). Dolayısıyla defter, çeşitli kayıtların suretlerinin bulunduğu toplama bir defter olduğundan Sahabe'ye dair kayıtların bulunduğu, muhasebenin tarihi olan 1101/1689-1690 esas alınacaktır.

Vakıflara ait muhasebe defterlerinden ilk üçünde olan kayıtlarda vakıf vazifelilerinin isim ve yevmiyelerine dair ayrıntılı bilgi mevcut değildir. Bunlar sadece yevmiyelerin aylık ve senelik toplamlarının verildiği muhasebe icmal defterleridir.

Tablo 1: Hz. Ali Cami' Vakfinın Vazife Giderleri

\begin{tabular}{|l|l|l|}
\hline $\begin{array}{l}\text { Receb 1106/Şubat-Mart 1695 } \\
\text { (30 günlük) BOA, HMH. d., 875 }\end{array}$ & $\begin{array}{l}\text { 1105 senesi (6 aylık) } \\
\text { Eylül-Şubat 1694 } \\
\text { BOA, MAD., 131. }\end{array}$ & $\begin{array}{l}\text { 1105 senesi (6 aylık) } \\
\text { Mart-Eylül 1694 } \\
\text { BOA, HMH. d., 820 }\end{array}$ \\
\hline Yevm 4 & Yevm 2 & Yevm 2 \\
\hline Şehr 120 & Şehr 360 & Şehr 360 \\
\hline
\end{tabular}

Tablo 2: Hz. Talha, Hazreti Zübeyr, Hz. Hasan-i Basrî ve Hz. Enes bin Mâlik Vakıflarının Vazife Giderleri

\begin{tabular}{|c|c|c|c|}
\hline $\begin{array}{c}\text { 1101/15 Ekim 1689-15 } \\
\text { Ekim } 1690 \text { (1 senelik) } \\
\text { BOA, KK. } 3377, \text { vr. 36- } \\
37\end{array}$ & $\begin{array}{c}\text { 1105/ Eylül-Şubat } 1694 \\
\text { (6 aylık) } \\
\text { BOA, MAD., } 131 \text { vr.1. }\end{array}$ & $\begin{array}{l}\text { 1105/ Mart-Eylül } 1694 \\
\text { (6 aylık) } \\
\text { BOA, HMH.d., } 820 \text { vr.1 }\end{array}$ & $\begin{array}{l}\text { Receb 1106/ Şubat- } \\
\text { Mart } 1695 \text { (30 günlük) } \\
\text { BOA, HMH.d., } 875 \text { vr.1 }\end{array}$ \\
\hline $\begin{array}{c}\text { Vazife hevâdân-ı } \\
\text { hazret-i Talha ve Hz. } \\
\text { Zübeyr ve Hz. Hasan-i } \\
\text { Basrî ve Hz. Enes bin } \\
\text { Mâlik } \\
\text { yevm } 52 \text { akçe } \\
\text { [Senelik] } 18720 \text { akçe }\end{array}$ & $\begin{array}{l}\text { Vakf-ı Hazreti Talha ve } \\
\text { Hazreti Zübeyr } \\
\text { Yevm } 52 \text { akçe } \\
\text { Şehr [?] } 210 \text { akçe } \\
\text { [6 aylık] } 9360 \text { akçe }\end{array}$ & $\begin{array}{l}\text { Vakf-ı Hazreti Talha ve } \\
\text { Hazreti Zübeyr } \\
\text { Yevm } 52 \text { akçe } \\
\text { Şehr [?] } 210 \text { akçe } \\
\text { [6 aylık] } 9360 \text { akçe }\end{array}$ & $\begin{array}{l}\text { Vakf-ı Hazreti Talha ve } \\
\text { Hazreti Zübeyr } \\
\text { Yevm } 52 \text { akçe } \\
\text { [ } 30 \text { günlük] } 1560 \text { akçe }\end{array}$ \\
\hline
\end{tabular}

Hz. Ali Câmii Vakfi müstakil olarak gösterilirken mütevelli ciheti belirtilmemiştir. Diğer dört vakfin tamamı bir mütevelli eliyle idare olunmaktadır. Buna karşılık dört vakfin bazı işleri ortaklaşa yapıldığı gibi bazı vazifeliler vakıflara özeldir ve yevmiyeleri de bir birinden farklıdır. Vakıfların en büyüğü $\mathrm{Hz}$. Zübeyr'in vakfidır, dolayısıyla vakfin bütün vazifelileri sadece onun türbe ve mescidinde görevlidir. Mescidin İmamı aynı zamanda müezzinlik de yaparken, birer hademe-i bevvâb ve hademe-i kiliddâr bulunuyordu.

Hz. Enes bin Malik ve Şeyh Hasan-ı Basrî́nin Türbesi ve Mescidi'nin ise kendilerine mahsus tek bir çalışanı vardır, o da kiliddârlıktır.

5 Defterde şehr (aylık) 210 akçe rakamı verilmişse de, günlük 52 akçeden aylık, 1560 akçe eder. 
II. Abdülhamid döneminde Basra Vilayet Meclisinden gelen mazbataya göre Hz Talha Türbesi'nin türbedarı bulunmuyordu. Evkaf Muhasebeciliği'nin araştırmasıyla durum netleşince padişah iradesiyle, vazifesi bizzat Hazîne-i Hassa-i Şâhâne (Emlâk-ı Hümâyûn İdâresi'nden) karşılanmak üzere 200 guruş aylık ile türbedar vazifesi 29 Cemaziyelahir 1304/25 Mart 1887 tarihinde Abdullah el-i'câbî'ye tevcih olunmuştu (VGMA, 982: 406). Abdullah ölünce de boş kalan türbedarlığa yine aynı şartlarla ve aylık 200 guruşla 15 Rebiülahir 1321/11 Temmuz 1903 oğlu Mehmed Efendi tayin edilmiştir (VGMA, 166: 132). 14 Şevval 1267/12 Ağustos 1851 tarihinde Hz. Zübeyr türbedarı ise Şeyh ibrahim Efendiydi (BOA, MVL. 106/39).

Vakıfların muhasebelerinin tutulduğu dördüncü defter, 1101/15 Ekim 1689-15 Ekim 1690 dönemine ait bir yıllık bir dönemi kapsamakla birlikte, vakıfların vazifelilerinin görevleriyle, isimleri ve yevmiyeleri birlikte kaydedilmiştir. Hz. Ali Camii'nin imam ve hatibi aynı kişi olup, Abdullah adında bir de müezzini bulunmaktadır. Vakfin senelik vazifeli gideri $(360+120) 480$ akçe iken, bu tarihte imam ve hatip olan Molla Cafer'e günlük 2 akçe, müezzin Abdullah’a yarım akçe ödenmektedir (BOA, KK. 3377, vr.41).

Tablo 3: Hz. Zübeyr, Hz. Talha, Hz. Enes ve Şeyh Hasan-ı Basrînnin türbeleri ve mescidlerine ait vakıfların günlük vazife/cihet ödemeleri:

\begin{tabular}{|c|c|c|c|}
\hline Vakıf & Vazife & Vazifelinin Adı & $\begin{array}{l}\text { Yevmiyesi } \\
\text { (akçe) }\end{array}$ \\
\hline \multirow[t]{6}{*}{ Ortak } & Mütevelli & - & 5 \\
\hline & Kennâs & Halef & 4 \\
\hline & Kennâs & Ahmed Macid & 4 \\
\hline & Ferrâş & Süleyman & 4 \\
\hline & Ferrâş & $\begin{array}{l}\text { Muhammed bin } \\
\text { Abdulmu'in }\end{array}$ & 4 \\
\hline & Sakâ & Bahaeddin & 4 \\
\hline Hazret-i Zübeyr & Hademe ve Bevvâb & Yusuf & 6 \\
\hline Hazret-i Zübeyr & İmam ve Müezzin & Molla Bekir & 4 \\
\hline Hazret-i Zübeyr & Hademe-i Kiliddâr & Mehmed & 4 \\
\hline Hazret-i Talha & Hademe & Ahmed & 5 \\
\hline Şeyh Hasan-ı Basrî & Kiliddâr & Ali bin Kasım & 4 \\
\hline Hazret-i Enes bin Mâlik & Kiliddâr & Yusuf & 4 \\
\hline \multicolumn{3}{|l|}{ Toplam } & 52 \\
\hline
\end{tabular}

H.1101/15 Ekim 1689-15 Ekim 1690 döneminde, bir yılda Hz. Talha, Hz. Enes türbeleriyle Hz. Zübeyr ve Şeyh Hasan-ı Basrî́nin türbe ve mescitlerine ait vakfin vazife/cihet ödemesi günlük 52 akçe olup, yıllık toplamları ise 18.720 akçedir ( BOA, KK. 3377, vr.36-37).

1689-1695 yılları arasındaki yedi yıllık bir döneme ait kayıtlarda, vakıf giderlerinde vazife ödemeleri hariç ilave bir masraf bulunmamaktadır. Ayrıca 18. yüzyıla ait vakıf kayıtlarına (şimdilik) rastlanmaması Osmanlı’nın bölgedeki idarî kesintisiyle ilgili olmalıdır.

Kullanılan Muhasebe defterlerinin dördü de vakıfların giderleriyle, özellikle vazifelilerin yevmiyelerine aittir. Vakıfların gelir kaynaklarını gösteren muhasebe kayıtlarına, vakıfların kuruluş şartlarını gösteren herhangi bir bilgi ve belgeye henüz rastlanılmadı. Bunlar Osmanlı'ya sonradan geçen bölgelerde bulunan vakıflar olduklarından, daha eskiye, Osmanlı öncesine dair kayıtlara Osmanlı Arşivi'nde ulaşmak zor görünmektedir. Bu bakımdan Sahabe vakıflarının vakfiye bilgilerinin mevcut olmamasının yanında, 
vakıf mevkufatının yeri ve nevini öğrenmek ancak yerel kaynaklara ulaşılmasıyla mümkün olabilecektir. Bu konuda en büyük verileri sağlayacak olan Basra'nın Osmanlı döneni Mahkeme Sicilleri'dir. Ne yazık ki gerek I. Dünya Savaşı'yla Osmanlı idaresinden çıktıktan sonra, gerekse İran-Irak savaşı ve I. Körfez Savaşı bölgenin yerel arşivine özellikle, Şeriye Sicilleri'ne büyük kayıplar yaşatmıştr.

\section{Osmanlı Dönemlerindeki Tamirler}

Türbe ve mescitlerin tamiriyle ilgili olarak meydana gelen gelişmeleri de çeşitli vesikalardan takip etmek mümkün olmakla birlikte kayıtlarda eksiklikler bulunmaktadır. 19. yüzyılın son çeyreği ve 20. yüzyılın başlarında II. Abdülhamid döneminde, meydana gelen mimari gelişmelere bağlı olarak çok sayıda eski eserin bakım ve tamiratı yapılmıştı. Özellikle mukaddes mekânlar Osmanlı tarihi boyunca korunmuş ve himaye edilmişti. İmparatorluğun en güneyindeki eyaletlerden olan Basra vilayeti merkezinde ve Zübeyr kasabasında bulunan Sahabe türbeleri de bu bağlamda defalarca tamir edilmeye girişilmiş, maliyeti çıkarılmış, fakat restorasyon bazen gerçekleşmiş bazen de yarım kalmıştır. Yarım kalan çalışmalarda, bürokratların ihmalleri, ağır yürüyen bürokratik işlemler ve devletin içinde bulunduğu zor durumun etkili olduğu muhakkaktır.

Bağdad vilayetinden gelen rapora (tahrirat) göre, Aşere-i mübeşşereden $\mathrm{Hz}$. Zübeyr ve $\mathrm{Hz}$. Talha ile ashab-ı kiramdan Enes bin Malik'in “merakıd-ı mübarekeleriyle” Hazret-i Zübeyr'in türbesinin bitişiğindeki caminin 68.000 küsur kuruşluk bir masrafla tamir olunacağı bildirilirken, bir de resmi gönderildi. Durum Sultan II. Abdülhamid'e arz edildiğinde bu camii ile türbelerin doğrudan doğruya kendi adına tamir edilerek masrafların (faturanın) Bağdat'ta bulunan kendi arazisi (has) hasılatından karşılanması için hazine-i hassaya izin verdiği gibi, bu gelen resmin gazetelerde ilanına dair irade-i seniyye çıkardı 18 Cemaziyelahir 1299/7 Mayıs 1882 (BOA, i.DH., 853/68435).

Türbelerin onarımına dair 3 Kanunevvel 1300 / 15 Aralık 1884 tarihini taşıyan ve keşif heyetince hazırlandıktan sonra Basra vilayet meclisinde onaylanan keşif raporuyla ekindeki keşif defteri (BOA, Y.MTV, 17/52) tamir bürokrasinin en canlı örneğidir. Daha önce başlatılan ve bir türlü tamamlanamadığı için tekrar tekrar baştan başlayan işlemler nedeniyle, geçen yıllar içinde binalar (türbe mescit vb.) daha da yıprandığı gibi alınan inşaat malzemesi ziyan olmaktadır.

Rapora göre yarım kalan, bir önceki seneye ait tamirat işi, keşif ve muayene olunduğunda türbenin iç taraflarının dörtgen (şekl-i murabba) kenar/yüzeylerinde (ezla'ında) girintiler ve köşelerindeki (zaviyelerindeki) bir takım oymalı çıkıntılarla bu duvarların üzerine inşa olunacak kubbe o sırada kötü durumda ve yarım halde bulunmaktadır. Bu hazırlanmış yüzey süslemeleri yerde bulunduğundan üzerindeki oyma ve çıkıntıların bazı yerleri şimdiden çatlamış ve duvarlar yıkılmaya yüz tutmuştur. Bu nedenle bu durumdaki malzemeyle inşaatın tamamlanmasının uygun olmayacağı bizzat müşahede olunmaktadır. Bununla beraber türbenin iyi bir görünüme kavuşturulması, üzerine de kubbenin düzgün ve sağlam bir sûretde yerleştirilmesi lüzumludur. Türbenin mevcûd tarması (çıkma/balkon) dahi sağlam bina edilmemiş olup, hatta yıkılmaya yakın olduğu mülahaza ediliyordu. Bundan dolayı aslında tarmanın da temelinden yıkıIıp, yeniden yapılması gerekiyordu. Kubbenin inşası için 20.700 guruş ve tarması için de 1.300 guruşa ihtiyaç bulunmaktaydı.

Rapora göre, Hz. Zübeyr türbesi için daha önce getirilen kâşi tuğlalar (kaşî tabûka) mevcûd olup, türbenin içinin bir boy kadar daha aşılması gerekiyordu ve bazı yerlerinin tamiri için hesaplan masrafi 7.425 guruşdu. Hz. Enes'in türbelerine yakın bir yerde açılacak bir kuyu ile türbenin tamirat 3.000 guruş tu- 
tuyordu. Türbelerin tamiri inşaatına bu seferki gereken meblağın yekûnu 41.425 guruşdur. Raporun sonunda meclis üyeleri ve ser-mimarın mühürleriyle "meclis-i idare-i Basra" mührü bulunmaktadır. Türbelerin dörtgen planlı olan beden duvarları, her biri 12 parmak kare ölçülerinde tuğla ile örülmüş, üstü muhtemelen klasik (külah, silindirik, armudî) formlarda bir kubbeyle örtülüdür. Kullanılan malzemeye bakıldığında, ahşap kısımlar için dut ağacı, duvarlar için kâşî tabûka (çinili sırlı tuğla), çatısı için döşeme tuğlası; ayrıca kireç kullanılmıştır. Kubbenin serpuşunun ise bakırdan yapılması planlanmaktadır. Dört türbe için toplam üç büyük, üç küçük kapı ve dört adet pencereyle camların maliyeti çıkarılmıştı. Kullanılan inşaat malzemesi, inşaat alanında uzman neccar ve inşaat ameleleri ile nakliye ücretleri hesaplanarak, keşif defterinde detayları verilmiştir (Bk. ekler).

19 yüzyılın sonu ve 20. yüzyılın başına ait tamirat faaliyetleriyle ilgili Basra vilayeti meclisi ile Evkaf Nezareti, Şura-yı Devlet ve diğer merkez daireleri arasında yapılmış bir dizi yazışma mevcuttur. 1899 yılına gelinmiş olmasına rağmen Sultan II. Abdülhamid'in masraflarını üstlendiği restorasyonun hala gerçekleşmemiş olduğu anlaşılmaktadır.

Bu defa da 17 Mart 1315/29 Mart 1899 tarihinde Basra vilayetinden Evkaf Nezareti'ne gönderilen yazıyla Hz. Talha, Hz. Enes ve Hz. Zübeyr mezarlarılla Hz. Zübeyr'in mezarı bitişiğinde olan camii ve minaresinin "hazîne-i evkâfca icrâ-yı ta'mîri”' arz ediliyordu. Mabeyn kitabetinden Evkaf Hazinesi'ne gelen irade sonrasında, Masarıfât İâresi'nden Basra'ya cevaben, "ta'mîrât için gereken keşif ve münâkısanın (açık artırma) yapılmasından sonra evrakının gönderilmesi ve tamirat masraflarının söz konusu vakıflarının gelirleriyle yapııı, yapılamayacağına dair muhasebelerinin durumunun bildirilmesi" isteniyordu (BOA, DH.MKT., 561/18; I.EV., 23/46).

Basra'dan gelen cevapla birlikte keşif defteri ekte gönderilmişti. Buna göre $\mathrm{Hz}$. Talha türbesinin 59.985, Hz. Zübeyr mezarının yanındaki caminin 57.109, Hz Enes türbesinin 29.506 guruş masrafla yenileneceğine dair keşif yapıldığı ve açık artırmadan sonra birinci 59.500, ikinci 56.500 ve üçüncüsü 28.850 guruş olmak üzere üç ayrı keşifle maliyet çıkarılmıştır. Evkâf ile Şûrâ-i Devlet yazışmasıyla tamirat faaliyetinin maktûen değil, emanet yoluyla gerçekleştirilmesi tavsiye olunuyordu. Diğer taraftan yapılan tetkikten sonra bu maliyetin vakıf hazinesinden karşılanamayacağı, ancak tamirat masraflarının vakfin R.1315/M.1899 senesi bütçesinden, Evkaf Hazinesi'ne olan tahsisatına mukabil karşılanabileceği, ilerde vakfin geliri tahakkuk ettiğinde mahsup edilebileceği de bildirilmişti (BOA, EV.MKT., 2511/28).

Ilerleyen tarihlerde Basra vilayetiyle, Evkaf Nezareti arasında yapılan Temmuz 1318/Temmuz 1902 tarihli yazışmalardan anlaşıldığına göre türbeler ve camiyle minaresi hala tamir edilmemiştir. Çünkü $R$. 1315 'te başlayan süreçte vakfin mali durumu tetkik edilmiş, keşif ve müzayede yapılmış, bir maliyet çıkarılmış ancak vakfin elinde bu masrafları karşılayacak, fazladan bir birikimi olmadığından Evkaf Hazinesi'nin, her yıl vakıflardan tahsisat nev'inden aldığı R. 1318 yılı hissesine mahsup olmak üzere tamirat gerçekleştirmesi karara bağlanmışt (BOA, EV.MKT, 2511/28. lef.1-4).

Nihayet Dahiliye Nezareti'yle, Basra vilayeti arasındaki 27 Mayıs 1319/9 Haziran 1903 tarihli yazışmaya göre vakıf gelirleri bir türlü istenen seviyeye ulaşamadığından hatta geçmiş yıllardan dahi Evkaf Hazinesi'ne bakayası bulunduğundan tamirat işi gerçekleşememiştir (BOA, EV.MKT, 2511/28. lef.4).

1899 yılından 1905 yılan kadar geçen altı yılık süreçte Basra valiliği ve vilayet meclisinden hem Sadaret'e hem de Maliye Nezareti'ne çeşitli tarihlerdeki yazılan mazbatalarla, birbirinin benzeri olup, tespit edilebilen yedi adet telgraf gönderilmişti. Basra valisi telgraflarında, tamiratı bir an evvel gerçekleştirilmemesinin “...mebâni-i İslâmîyenin ihyâsı hakkındaki emr-i fermân-ı hümâyûna mugayyir..." (BOA, BEO, 2153/161431) olduğunu ısrarla vurguluyor, para sorunun çözülmesi için bürokratik işlemlerin hız- 
landırılmasını ve aksi halde oluşacak mahzurları bildiriyordu. Vakfin geliri yeterli olmadığından, R. 1315 senesinden beri bakiyesi olan 144.850 guruş sağlanamadığı için inşaat işi yarım bekliyordu.

Sadaret gelen telgrafları Maliye Nezareti'ne iletiyor Maliye ise Basra'ya yazarak vakıf bütçesinin durumunu soruyor, cevap gelinceye kadar aylar geçiyordu. Maliye tarafindan gönderilen tezkirelerde vakfin Evkaf Nezareti'ne olan yıllık tahsisatına mahsuben geçen senenin (sene-i sabıka) bütçesine, bazen de "sene-i haliye" bütçesinden ödenmesi (tesviyesi) isteniyordu. Basra valisi cevabi telgraflarında bazen geçen sene bütçesine bakaya kaydedilmesinin zorluğunu ifade ederken, bazen de bütçeyi yapabilmek için gereken havalenameyi talep ediyor ve bürokratik gecikmeler dolayısıyla bütçe dönemi geçiyordu. İçinde bulunulan sene (sene-i haliye) bütçesine mahsup edilmesi ise bir yıl daha gecikilmesi anlamına geldiğinden, bir an önce tamiratın yapılmasına izin verilmesini, aksi halde üç türbenin ve mescidin tamamen yıkılacağını bildiriyordu. ${ }^{6}$

Bununla beraber Basra valisi iki ayrı telgrafinda neredeyse birbirinin aynı ifadelerle, padişah iradesi gereğince, tamirlere gereken paranın Maliye Nezareti'ne uzun zamandır, arz edilmiş olmasına rağmen şimdiye kadar gereken izinlerin verilmediğini "mevki' hasebiyle her yerden ziyaret-i Basra'ya tevârüd edegelen seyyâh ve zevâd-ı Müslim-i muhtelifeye karşı merâkıd-ı mezkûrenin hal-i harabda bulundurulması gayr-ı münâsib ve şi' ar-ı diniyye-i islamiyeye" ve İslam halifesinin fermanına muhalif bulunduğuna işaret ediyordu (BOA, BEO. 2584/193773 lef 5). Diğer telgraf da bu ifadelerle başlayıp, harap olmaya yüz tutmuş “merâkıd-ı mübarekeden” Hz. Zübeyr türbesiyle ve bitişiğindeki cami büsbütün yıkılacak bir raddeye gelmiş olduğundan buranın ziyaret ve içinde ibadet edilmesinin tehlike arz ettiğini, Zübeyr kasabası müdürünün tamirat yaptrılıncaya kadar mescidin kapatlarak, kimsenin girmemesi için kapısına bir memuru bekçi koymak için izin istediğini yazıyordu (BOA, BEO, 2620/196433).

Bu şekilde 1899 yılından 1905 yılı Ağustos ayına kadar altı muhasebe dönemi geçmesine rağmen, yazışmalar, kısır bir döngü halinde sürüp gitmektedir. Osmanlı vakıf müessesesi son derece nizam içinde yürütülmesine rağmen uzak bir vilayet olan Basra'daki söz konusu vakıflar ihmale uğramışlardır. Türbe ve mescitlerin vakıfları olmasına rağmen, gereken bakım hizmetlerinin verilemediği anlaşılmaktadır. Bölgesel güçlü ailelerin ve Arap aşiretlerinin isyanları bölgeyi güvensiz ve yönetimi istikrarsız bir hale getirmekteydi 7. Vakıf eserleri/hayratı vakıfların verdiği bakım-onarım sayesinde yüzlerce yıl ayakta kalabiliyordu. Ancak yine de vakıf yöneticilerinin yahut yerel yöneticilerin ihmalleri, vakıf gelir kaynaklarının azalması veya ziyan edilmesi gibi nedenlerle bunun mümkün olamadığı zamanlar olmaktaydı. Merkez taşra arasındaki mesafenin uzaklığı nedeniyle, bürokratik yazışma ve haberleşmenin zaman alması gibi nedenler de karar verilen tamir işlerini geciktiriyor dolayısıyla geçen sürede eserler yıkılıp yok olabiliyordu.

Basra Osmanlı idaresinde bulunduğu yüzyıllar boyunca istikrarın tam sağlanamadığı vilayetlerden biriydi. Osmanlı-iran arasında bir mücadele sahası olmasının yanında, içeride Arap aşiretler arasındaki yerel problemler de bölgenin huzurunu bozan olaylardı. 1917'de I. Dünya savaşı sırasında Irak cephesinin dolayısıyla Bağdat'ın kaybedilmesiyle Basra da Osmanlı idaresinden çıkt. Bölgede Irak Devleti kurulduktan sonra, Sahabe türbelerinin akıbeti belirsizdir. 1980-1988 Irak-Iran savaşları ve 1991 I. Körfez savaşı sırasında Basra ağır hasar gördü.

6 Bk. (BOA, BEO, 2559/191918; BEO, 2620/196433; BEO, 2662/197632; BEO. 2584/193773 lef 1-5; BEO, 2153/161431, lef 1-2).

7 Basra vilayetine yakın bir yer olan Hazret-i Zübeyr kasabasında asayişi bozucu halin zuhurundan dolayı gereken önlemlerin alınarak karışıklığın bastıııması (BEO, 460/34463. 18 Safer 1312/21 Ağustos 1894). Fesad çıkaranların Hazret-i Talha Camii yakınında mevzi almış bulunan asker müfrezesine silah çektiklerine ve askerin karşılık vermesi üzerine Zübeyr kasabasına çekildikleri (BEO, 1619/121373. 25 Şevval 1318/15 Şubat 1901). 


\section{Sonuç}

İslam medeniyetinin kurucularından ve ilk Müslümanlardan olan $\mathrm{Hz}$. Talha, Hz. Enes ve Hz. Zübeyr'in isimleri Basra ile bütünleşmiş durumdadır. Türbelerinin burada bulunması, bölgeyi Hanefilerin önemli bir ziyaretgâhı haline getirmişti. İslam ve Türk-i̇slam medeniyetinin önemli bir parçası olan vakıflar ve onlara ait kayıtlar sayesinde, Osmanlı İmparatorluğu'nun en uçta ve kontrolü tam sağlanamayan bir bölgesinde bulunmalarına rağmen, türbe ve mescitlerin durumunu takip etmek mümkün olabilmektedir. Özellikle vakıf muhasebe defterleriyle, 19. ve 20. yüzyıllardaki tamiratlara dair arşiv kayıtları sayesinde birkaç yüzyıllık bir dönemle ilgili bir çalışma yapılabilmektedir.

Burada dikkati çeken en önemli unsur, bir şehir Osmanlı hakimiyetine girmeden önce burada kurulmuş olan İslamî vakıfların, söz konusu yer Osmanlı idaresine girdikten sonra, bozulmayıp, şartlarına riayet edilerek devam ettirilmesidir. Sözü edilen yerin eski bir İslam toprağı ve vakıfların da Sahabe'ye ait olması nedeniyle, Osmanlı idaresinin bu konuda daha hassas davrandığını da unutmamak gerekir. Bilindiği üzere Osmanlı padişahları eski İslam coğrafyasında giriştikleri seferleri sırasında, ilk iş olarak mübarek zatların türbelerini ziyaret ederler, gerekirse tamir ettirirler; selatin camileri bulup, ilk Cuma namazını kılarlar ve adlarına hutbe okuturlardı. Bu bakımdan, Sultan Süleyman zamanından itibaren Irak bölgesinde bulunan İslam eserlerinin ve türbelerin koruma altnna alındığı, bilinmekle beraber, Osmanlı Arşiv kayıtlarında, Sahabe'nin türbe ve mescitlerine dair ilk vakıf kayıtları 17. yüzyılın sonuna aittir. En azından, şimdilik tespit edebildiklerimiz 1690'lardan başlamaktadır.

18. yüzyılda, bölgedeki Osmanlı hakimiyetinin kesintiye uğraması nedeniyle, bu devirde, vakıf işlerinin tam takip edilemediği ve bu işlerle ilgili kayıtların sağlıklı bir şekilde tutulamadığı anlaşılmaktadır. Merkezi İstanbul'da olan ve hayratı Basra'da inşa edilmiş vakıfların bu yüzyıldaki işlem ve kayıtlarında bir aksama bulunup, bulunmadığı da ayrıca araştrıımalıdır. Osmanlı hakimiyeti yeniden sağlanıncaya kadar geçen sürede, vakıf türbe ve mescitlerinin bakımsız kaldığı anlaşılmaktadır. 19. yüzyıla ait, Osmanlı bürokrasindeki yazışmalardan, vakıf eserlerinin tamir edilmesine dair pek çok girişim olduğu görülmektedir. Bu girişimler önemli olmakla birlikte, coğrafyanın uzaklığı, bürokrasinin yavaş işlemesi ve bölge ile iletişimin iyi sağlanamamasından dolayı kısmen başarılı olunmuştur. Buradaki halkın yaşam tarzı ve bölgedeki mezhep mücadelesi göz önünde bulundurulduğunda bu eserlerin, yüzyıllarca kadar varlığını koruyabilmeleri son derece önemlidir. 


\section{Kaynakça}

\section{Arşiv Kaynakları}

\section{T.C. Cumhurbaşkanlığı Devlet Arşivleri Başkanlığı Osmanlı Arşivi (BOA)}

Bâb-I Ali Evrak Odası (BEO), 302/22622; 460/34463; 1619/121373; 2153/161431; 2559/191918;

2620/196433; 2662/197632; 2584/193773.

Dahiliye Mektubi Kalemi (DH.MKT.), 561/18.

Evkaf Mektubi Kalemi (EV.MKT.), 2511/28.

Haremeyn Muhasebesi Defterleri (HMH. d.), 820, 875.

İradeler Evkaf (i.EV.), 23/46

Kamil Kepeci Defterler (KK.), 3377

Maliyeden Müdevver Defterler (MAD.), 131.

Meclis-i Vala (MVL), 106/39.

Yıldız Mütenevvi Maruzat (Y.MTV.), 17/52.

\section{Vakıflar Genel Müdürlüğü Arşivi (VGMA)}

VGMA Defter, 166, 982.

\section{Araşturma ve incelemeler}

Ali Cevad (1313). Memâlik-i Osmâniye'nin Tarih ve Coğrafya Lügat, İstanbul: Mahmud Bey Matbaası. Aydınlı, Abdullah-i̇smail L. Çakan (1991). Aşere-i Mübeşşere. Türk Diyanet Vakfi islam Ansiklopedisi (DiA), (3): 547.

Bakır, Abdülhalik (1992). Basra. DiA, (5), 108-112.

Canan, İbrahim (1995). Enes B. Mâlik. DiA, (11), 234-235.

Çekim, Taif (1996). 1551 M (959 H.) Tarih ve 282 No'lu Tapu Tahrir Defterine Göre Basra. Fırat Üniversitesi Sosyal Bilimler Enstitüsü, Basılmamış Yüksek Lisans Tezi.

Efendioğlu, Mehmet (2013). Zübeyr b. Avvâm. DiA, (44), 522-524.

Ebû Cafer Muhammed bin Cerir'üt-Taberî, (2007). Tarih-i Taberî (trc. M. Faruk Gürtunca) IV. Sağlam Yayınları.

Erul, Bünyamin (2010). Talha b. Ubeydullah. DiA, (39) 504-505.

Eroğlu, Cengiz- Murat Babuçoğlu ve Orhan Özdil (2005). Osmanlı Vilayet Salnamelerinde Basra. GSE Yayınları.

Günümüz Türkçesiyle Evliyâ Çelebi Seyahatnâmesi (2010). (Haz. S. Ali Kahraman-Yücel Dağlı), 4. Kitap 2. Cilt. Yapı Kredi Yayınları.

Halaçoğlu, Yusuf (1992). Basra-Osmanlı Dönemi. DiA, (5), 112-114.

ibn Battûta Seyahatnâmesi (2010). (Çeviri, İnceleme ve Notlar A. Sait Aykut), Yapı Kredi Yayınları.

Mehmed Hurşid Paşa (1997). Seyahâtnâme-i Hudûd. (Haz. Alâattin Eser). Simurg Yayınları.

Poş, Abdullah (2011). XIX. Yüzyılın Sonlarında Irak'taki Şiî Nüfus ve Caferî Toplumunu Tahrik Faaliyetleri. Milel ve Nihal Inanç, Kültür ve Mitoloji Araşttrmaları Dergisi, (VIII/3-Eylül-Aralık), 47-76.

Allahverdi, Reyhan Şeyhin (2016). Kafkas Fatihi Özdemiroğlu Osman Paşa, İstanbul: Çamlıca Basım Yayın. Taberî, (1991). Milletler ve Hükümdarlar Tarihi (trc. Zâkir Kadirî Ugan-Ahmet Temir). I-V, MEB Yayınları. 
Basra'daki Sahabe Türbe ve Mescitleri ile Vakıflarının Osmanlı Dönemindeki Durumu

\section{EKLER}

Ek.1 2007 Yılında bombalanan Hz. Talha Türbesi

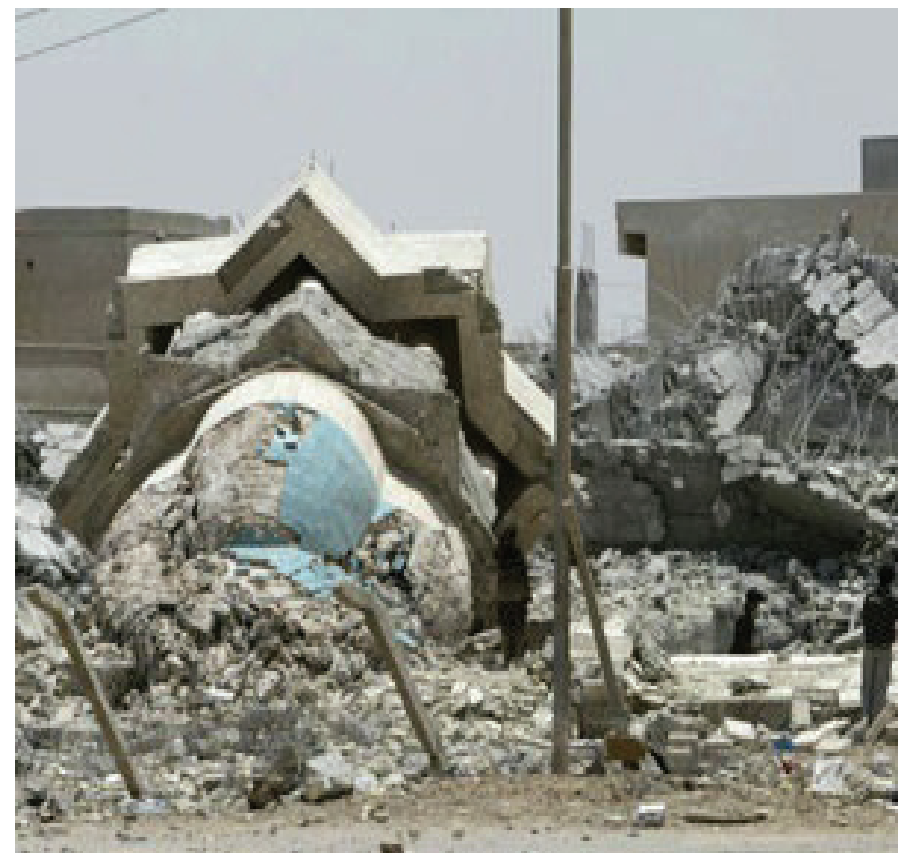

Ek.2 İnşaat Keşif Defteri: BOA, Yıldız Mütenevvi Maruzat (Y.MTV.), 17/52.

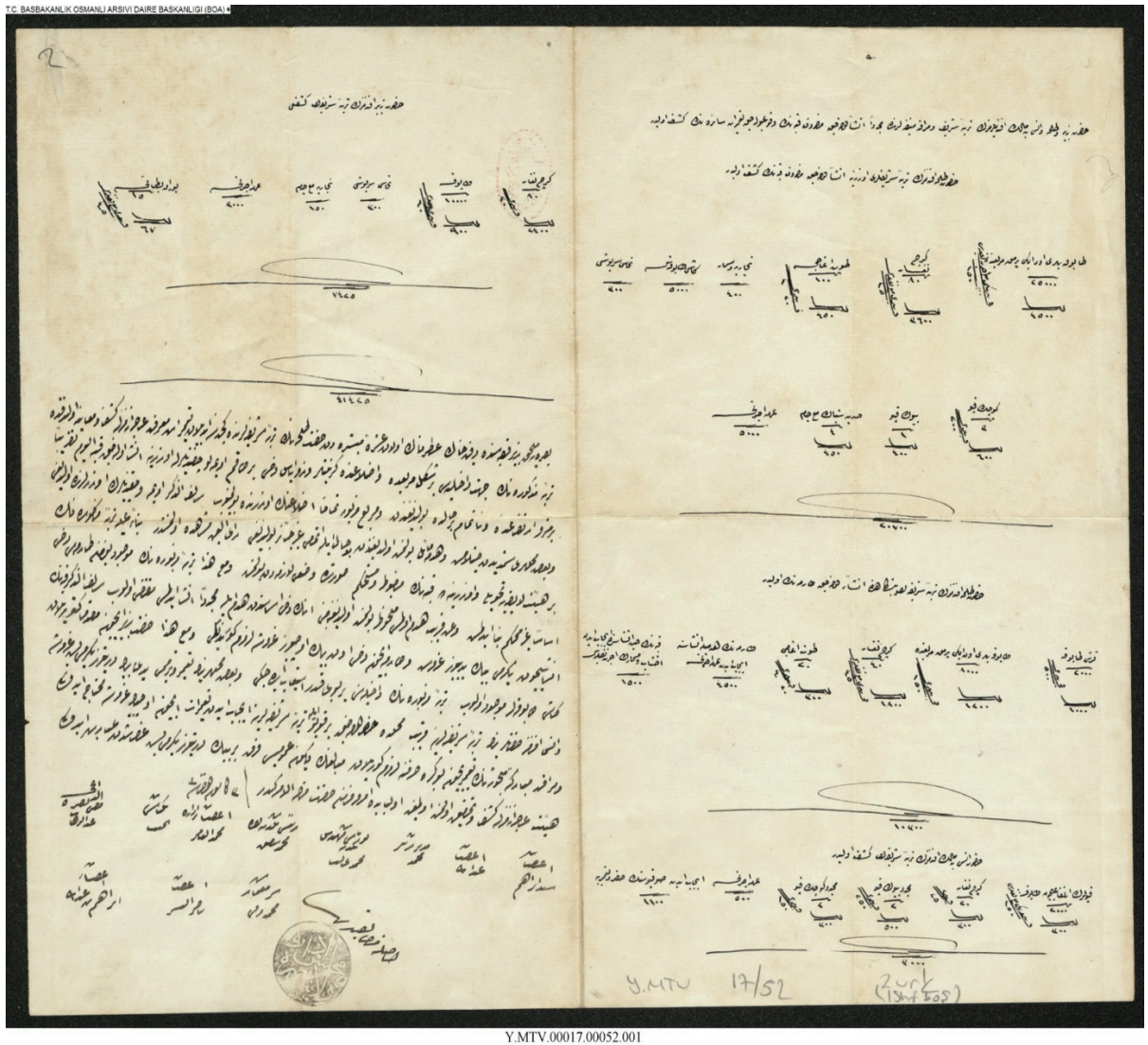


Ek.2 İnşaat Keşif Defteri: BOA, Yıldız Mütenevvi Maruzat (Y.MTV.), 17/52.

\begin{tabular}{|c|c|}
\hline \multicolumn{2}{|c|}{ Hazret-i Talha Efendimizin türbe-i şerifleri üzerine inşa' olunacak mazrûf kubbenin keşf-i evvelidir } \\
\hline Malzemenin Ölçüsü ve Birim Fiyat - Hizmet Bedeli & Meblağ (guruş) \\
\hline $\begin{array}{l}\text { Tabûka beheri iki parmak murabba'ında } 25000 \text { adet beher bini ma' ücret-i } \\
\text { nakliyesi } 150 \text { guruş }\end{array}$ & 4500 \\
\hline beheri ma' nakliyesi 45 & 3600 \\
\hline Dut ağacı 100 adet $\quad$ fî aded $4-20$ & 450 \\
\hline Neccâriye ve mesmâr & 400 \\
\hline Kâşi tabûkası & 5000 \\
\hline Nuhhâs serpûş & 300 \\
\hline Küçük kapu 3 adet fi beheri 200 & 600 \\
\hline Büyük kapu 1 adet & 400 \\
\hline Cedîd şibâk? ma' câm 4 adet & 450 \\
\hline Amele ücreti & 5000 \\
\hline Cem'an & 20700 guruş \\
\hline \multicolumn{2}{|c|}{ Hazret-i Talha efendimizin türbe-i şerîfeleri pişgâhında inşâ' olunacak tarmanın [keşf-i] evvelidir } \\
\hline Ferş tabûka 2000 aded fî beher bini 500 & 1000 \\
\hline Tabûka beheri 12 parmak murabba'ında 8000 aded fî beher bini 150 & 1200 \\
\hline Kireç (?) 40 fi beheri ma' nakliyesi 45 & 1800 \\
\hline Dut ağacı 20 aded fî beheri 4 guruş 20 para & 300 \\
\hline Tarmanın hedmiyle inşâsına icâb eden amele ücreti & 4500 \\
\hline Kubbenin hîn-i inşâsında icâb eden ahşâb ve mesmârın ücret-i nakliyesi & 1500 \\
\hline Cem'an & 10300 guruş \\
\hline \multicolumn{2}{|c|}{ Hazret-i Enes bin Malik efendimizin türbe-i şerîfeleri keşf-i evvelidir } \\
\hline Kapuların irtifa' içün tabûka 2000 aded beher bini ma' nakliyesi 150 & 300 \\
\hline Kireç $\quad$ (?) 20 fî beheri 25 & 300 \\
\hline ...? büyük kapu 2 aded fî beheri 250 & 500 \\
\hline Amele ücreti & 500 \\
\hline İcâb eden su kuyusunun hafr ve ta'miri & 1100 \\
\hline Cem'an & 3000 guruş \\
\hline \multicolumn{2}{|l|}{ Hazret-i Zübeyr efendimizin türbe-i şerîfleri keşf-i evvelidir } \\
\hline $\begin{array}{l}\text { Kireç (?) } 80 \text { fî beheri } 30 \\
\text { burak bitanı? } \quad 15 \text { beheri ma' }\end{array}$ & 2400 \\
\hline Tabûka 1000 aded fî beheri ma' nakliyesi 60 & 900 \\
\hline Nuhhâs serpûş & 300 \\
\hline Neccâriye ma' câm & 150 \\
\hline Amele ücreti & 3000 \\
\hline Nakliyesi 45 & 67 \\
\hline Cem'an & 7425 guruş \\
\hline \multicolumn{2}{|l|}{ Cem'an 41425 guruş } \\
\hline
\end{tabular}




\section{Ethical Principles}

Authors submitting their work to Journal of Waqfs are obliged to meet the ethical principles stated below:

Authorship of the paper: Authorship should be limited to those who have made a significant contribution to the study. Authorship has been agreed prior to submission and that no one has been 'gifted' authorship or denied credit as an author ("ghost authorship").

Acknowledgements: Those (institutions and financial resources) who have provided support but have not contributed to the research should be acknowledged in an Acknowledgements section.

Originality and purity of plagiarism: The submitted work should be entirely owned by the authors. If the work of other researchers is included in the manuscript, it should be cited appropriately and listed in the references. The author is obliged to check the manuscript with one of the plagiarism prevention software, Turnit-in or iThenticate, and submit the similarity report to the journal for application. Manuscripts with a similarity rate of $15 \%$ or more will not be considered.

Ethics committee permission and approval: Authors are required to describe in their manuscripts ethical approval from an appropriate committee and how consent was obtained from participants when research involves human participants.

Redundant publication: Authors are expected to submit original, previously unpublished content to Journal of Waqfs. It is unacceptable to submit the work for a review to another journal at the same time.

Salami publication or salami slicing: Authors should not present the results of a research as separate publications in academic appointments and promotions by disaggregating and disseminating the results of the research in an inappropriate manner and disrupting the integrity of the research.

Data access and retention: Authors are required to submit the raw data of their research when requested by the editors and referees, and keep this data after publication.

Fundamental errors in published works: When an author discovers a significant error or inaccuracy in his/her own published article, it is the author's obligation to promptly notify the journal editor and cooperate with the editor to retract or correct the paper.

\section{Contact Information}

Republic of Turkey Ministry of Culture and Tourism

General Directorate of Foundations

Department of Culture and Registration

Journal of Waqfs

Atatürk Bulvarı. No:10 06050 Ulus / ANKARA / TÜRKIYE

Tel: (0312) 5096000 • Faks: (0312) 3244722

vakiflardergisi@vgm.gov.tr•e-posta:vakiflaryayin@vgm.gov.tr

web:

www.vgm.gov.tr

http://dergipark.gov.tr/vakiflar 